\title{
Optimizing application of entomopathogenic nematodes to manage large pine weevil, Hylobius abietis L. (Coleoptera:Curculionidae) populations developing in pine stumps, Pinus sylvestris
}

\author{
Aoife B. Dillon ${ }^{\text {a,* }}$, Martin J. Downes ${ }^{\text {a }}$, Declan Ward ${ }^{\text {b }}$, Christine T. Griffin ${ }^{\text {a }}$

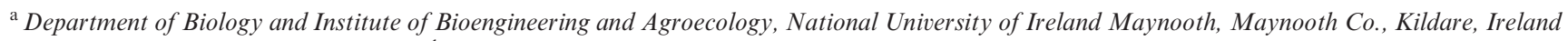 \\ ${ }^{\mathrm{b}}$ Coillte Research, Newtown Mountkennedy, Co., Wicklow, Ireland \\ Received 26 June 2006; accepted 6 November 2006 \\ Available online 14 November 2006
}

\begin{abstract}
Hylobius abietis develops in stumps of recently felled coniferous trees, and adults emerge to feed on and kill young seedlings. Entomopathogenic nematodes applied to stumps containing late instar larvae and pupae can reduce the number of adults emerging. We tested the feasibility of reduced application rate and volume during a broader window of application in field trials in 2004 and 2005 . Application at the standard rate of 3.5 million infective juveniles per stump suppressed the number of adults emerging by up to 79-85\% relative to controls for Heterorhabditis downesi, 57-64\% for Steinernema carpocapsae and 51-56\% for S. feltiae. When the application rate was halved, only $H$. downesi gave a significant reduction in emergence (75-79\%). Nematodes applied in April, May or June significantly reduced weevil populations, and application of nematode-killed insects in May was as effective as an aqueous suspension. A fourfold reduction in application volume from 500 to $125 \mathrm{ml}$ per stump did not affect the percentage of weevils parasitized, and stump excavation revealed that even at the reduced volume, both $S$. carpocapsae (ambusher) and $H$. downesi (cruiser) parasitized weevils $40-49 \mathrm{~cm}$ from the bole and $40-$ $49 \mathrm{~cm}$ below soil level. A higher percentage of larvae $(60 \%)$ were infected than either pupae $(36 \%)$ or callow adults $(18 \%)$. Our trials show promise for expanding the use of entomopathogenic nematodes against pine weevil, as the standard application rate can be halved, and the volume reduced to $25 \%$ of the standard without significant loss of efficacy, and there is a wide window of opportunity for application, even when soil temperatures are as low as $9^{\circ} \mathrm{C}$.
\end{abstract}

(c) 2006 Elsevier Inc. All rights reserved.

Keywords: Hylobius abietis; Steinernema feltiae, Steinernema carpocapsae, Heterorhabditis downesi; Entomopathogenic nematodes; Cadaver application; Nematode dispersal; Low temperature; Foraging strategy; Ambusher; Cruiser; Application rate

\section{Introduction}

Damage caused to young transplanted coniferous seedlings by adults of the large pine weevil, Hylobius abietis (L.) (Coleoptera:Curculionidae), has earned this insect the reputation as one of the most important pests of reforested sites in Northern and Eastern Europe (Leather et al., 1999; Langstrom and Day, 2004). Adult weevils are attracted to clearfelled sites by the volatiles emitted by the stumps of recently felled coniferous trees (Nordlander, 1987;

\footnotetext{
* Corresponding author. Fax: +35317083845.

E-mail address: aoife.dillon@nuim.ie (A.B. Dillon).
}

Nordlander et al., 1986). Females lay their eggs in, or near the stump (Eidmann, 1974; Nordenhem and Nordlander, 1994; Norlander et al., 1997). Development, within the stump, from egg to adult takes 12-36 months, but is influenced by a number of factors including felling date, tree species and temperature (Leather et al., 1999; Moore et al., 2004). Following emergence, the adults feed on the bark of young transplants used to restock the clearfelled site. Such seedlings may remain susceptible to weevil attack for the first 2-3 years (Petersson et al., 2005). In the absence of control measures, losses due to adult weevil feeding can reach up to $100 \%$ in restocking sites in the UK, with an average of $50 \%$ in the first few years after establishment 
(Heritage and Moore, 2001). It has been estimated that if insecticides were not used, losses in Europe due to adult feeding would be 140 million Euros (175 million USD) annually (Langstrom and Day, 2004).

Given its economic implications, control of the large pine weevil is essential for development of sustainable forestry. Current control measures in the UK and Ireland involve treatment of seedlings with the pyrethroids cypermethrin or alpha-cypermethrin before and after planting, but the use of chemical insecticides raises a number of concerns, both in terms of environmental and worker safety and efficacy. Chemical control is not completely effective, as adult $H$. abietis avoid seedlings treated with certain insecticides and seek out untreated seedlings (Rose et al., 2005). Although feeding is depressed in the presence of insecticides, death due to insecticide poisoning may take a number of weeks, during which time the weevils may continue to damage seedlings (Rose et al., 2005). As a participant of the sustainable forest management (SFM) agreement, the European Union has agreed to reduce pesticide use when developing forestry. Although a number of natural enemies have been identified (reviewed by Kenis et al., 2004), to date only entomopathogenic nematodes have been employed as biological control agents on a semioperational scale as part of an integrated management program for H. abietis (Evans et al., 2004; Torr et al., 2005).

Entomopathogenic nematodes (EPNs) of the families Steinernematidae and Heterorhabditidae (Nematoda: Rhabditida) are insect parasites that have been successfully used to control several important insect pests (Grewal et al., 2005). Their pathogenicity is partly due to their symbiotic association with bacteria of the genera Xenorhabdus and Photorhabdus, respectively (Forst et al., 1997).

The free-living infective juveniles (IJs) actively seek out insects in the soil. The IJs enter the insect through the natural openings and, in the case of Heterorhabditis, through the cuticle. In the insect hemocoel, the IJs release their symbiotic bacteria from their gut, leading to death of the insect. The nematodes reproduce in the insect cadaver, producing thousands of fresh IJs, which emerge from the cadaver 2-3 weeks after infection, once the cadaver resources have been exhausted. Several species of EPNs are produced in bioreactors (Shapiro-Ilan et al., 2002; Grewal et al., 2005). The nematodes are normally applied to the soil in an aqueous suspension, but application of nematode-killed insects to the soil has also been successful (Jansson et al., 1993; Jansson and Lecrone, 1994; Creighton and Fassuliotis, 1985; Shapiro-Ilan et al., 2003).

All stages of $H$. abietis are susceptible to entomopathogenic nematodes, though immature weevils are more susceptible than adults (Pye and Burman, 1978; Collins, 1993; Brixey, 2000): Following the success of early Swedish trials using Steinernema carpocapsae (Weiser) (Burman et al., 1979), research has focused on targeting the sedentary immature weevils developing in the stumps, with a view to suppressing the population of adult weevils emerging on a site. Following small-scale trials (Brixey, 2000), the UK Forestry Commission instigated large-scale trials using $S$. carpocapsae. In 2003, the UK Forestry Commission applied $S$. carpocapsae to approximately 200 ha at an application rate of 3.5 million IJs/stump in a volume of 0.5 liters. Approximate costs using this system were $€ 160 /$ ha for application and $€ 1,200 /$ ha for $S$. carpocapsae (Torr et al., 2005). In 2005, the area treated was increased to 500 ha, and total costs fell to $€ 500 /$ ha (S. Heritage pers. comm., 2006). While $S$. carpocapsae is widely used in the UK, Dillon et al. (2006) concluded that with an application rate of 3.5 million IJs/stump, population suppression was best achieved using heterorhabditids, particularly Heterorhabditis downesi Stock, Griffin \& Burnell. Although not commercially available, $H$. downesi is the only indigenous heterorhabditid in the Republic of Ireland, so the use of this EPN is preferable from an ecological perspective.

As a narrow window of application could make the treatment of large areas impractical, timing of application (April, May or June) was investigated in the present trials. We also tried a reduced application rate (1.75 million IJs/stump) and volume $(125-500 \mathrm{ml})$ to reduce costs. Access to large volumes of water may restrict the feasibility of treating large areas with nematodes. The effect of carrier volume was investigated for $H$. downesi and $S$. carpocapsae as these species reportedly display markedly different foraging strategies (cruiser and ambusher, respectively). Two different application methods (aqueous suspension and nematode-killed insects) were compared. Although most applications use IJs in an aqueous suspension, these conditions are markedly different to what occurs in nature, and may in fact cause osmotic stress and affect nematode survival, infectivity, development and dispersal (Perez et al., 2003; Shapiro-Ilan and Lewis, 1999; Lewis et al., 2002; Shapiro-Ilan and Glazer, 1996).

The purpose of this study was to find the range of conditions under which EPNs [S. carpocapsae, S. feltiae (Filipjev) and $H$. downesi] can be applied to stumps to control adult $H$. abietis populations, and reduce costs.

\section{Materials and methods}

\subsection{Experimental sites}

Field trials were conducted in 2004 and 2005. The 2004 trial was in Emo Forest in Co. Laois in central Ireland ( $N=53^{\circ} 05^{\prime} 48^{\prime \prime}, W=007^{\circ} 12^{\prime} 22^{\prime \prime}$; elevation $\left.28 \mathrm{~m}\right)$. The 2005 trial was in Donadea Forest, Co. Kildare $\left(N=55^{\circ} 22^{\prime}\right.$ 28", $W=006^{\circ} 46^{\prime} 52^{\prime \prime}$, elevation $64 \mathrm{~m}$ ). Trees (Scots pine, Pinus sylvestris L.) were felled in December 2002 and 2003, respectively (16-18 months prior to nematode application). Soil on both sites was deep peat. Only stumps with a diameter greater than $20 \mathrm{~cm}$ were chosen.

\subsection{Nematodes}

S. carpocapsae All strain $\left(\right.$ Carponem $\left.{ }^{\mathrm{R}}\right)$ was obtained from Koppert, Berkel en Rodenrijs, Holland. Nematodes were supplied on an inert carrier in a wettable powder formulation less than a week before use and stored at $9{ }^{\circ} \mathrm{C}$ 
until required. On the day of application the product was suspended in water to the desired concentration of nematodes. S. feltiae 4CFMO and H. downesi K122 were produced in late instar larvae of the wax moth Galleria mellonella (L.) at $20^{\circ} \mathrm{C}$ (Woodring and Kaya, 1988). S. feltiae 4CFMO was isolated from a clear felled site in Mayo, Ireland where the previous crop had been pine (Dillon, 2003), and $H$. downesi $\mathrm{K} 122$ was recovered from grasslands in Wexford, Ireland (Stock et al., 2002). Nematode-killed insects were placed on White traps. IJs were harvested daily for 3 days from the time of first emergence and harvests were pooled. Harvested IJs were washed by sedimentation in three changes of tap water and stored for up to a week at $9^{\circ} \mathrm{C}$. In the trial investigating the effect of timing of nematode application on weevil emergence (Section 2.4), nematodes applied on different dates were from separate batches in order to minimize differences in storage period. In 2004, storage was in $50 \mathrm{ml}$ aliquots $(5000 \mathrm{IJ} / \mathrm{ml})$ in $9 \mathrm{~cm}$ diam. food containers with snap-on lids. In 2005, nematodes were bulk stored at 5000-7000 IJs/ml in 5-L bottles (approx 4 L per bottle) with constant aeration. In both years, nematodes were transported to the field site in 5-L bottles, which were continuously shaken to aerate the suspension.

To produce nematode-killed insects for the cadaver application on May 6th 2005, groups of $50 \mathrm{G}$. mellonella larvae were exposed to $200 \mathrm{IJ}$ /larva on filter paper, on either April 25th (H. downesi), or April 29th (S. carpocapsae and S. feltiae) and were incubated at $20^{\circ} \mathrm{C}$. In order to estimate the number of IJs produced per cadaver, $100 \mathrm{G}$. mellonella from each of the three nematode treatments were placed on White traps (10 insects per trap) on May 9th and the IJs harvested and counted every 3-4 days over the following 16 days. $S$. carpocapsae began to emerge on May 10th while $S$. feltiae and $H$. downesi began to emerge on May 11th. The number of nematodes per harvest was based on three replicate counts. Harvests per White traps over 16 days were calculated and emergence per cadaver estimated.

\subsection{Effect of nematode application rate on weevil emergence}

Each of the three nematode species ( $S$. carpocapsae All strain, S. feltiae 4CFMO and $H$. downesi K122) was applied at two rates $(3.5$ and 1.75 million $\mathrm{IJ} / \mathrm{stump}$ in $500 \mathrm{ml}$ of water) in the first week of June. The dry needle litter was removed and the nematode suspension was poured onto the soil around the stump in a band approximately $5 \mathrm{~cm}$ wide, from where they were expected to move out in search of available hosts. The litter was then replaced to protect the nematodes against ultraviolet radiation and desiccation. The experiments were set out in a randomized block design. Each block contained 1 replicate (stump) of each nematode treatment and either 1 (2004) or 3 (2005) untreated control stumps. Eight (2004) or 10 (2005) blocks were treated.

Stumps were covered with baited insect traps designed to catch emerging adults. A pyramid of black cotton overlaying a bamboo tripod (i.e., a tent) covered each stump (Dillon et al., 2006). Insect emergence traps were erected 6 weeks after nematode application and checked 8, 10, 12, 14 and 16 weeks after nematode application. In 2005 traps were also checked after 18 weeks. At each assessment date, trapped insects were removed and counted. Based on the design of the tents, it was likely that their presence could modified the environment around the stumps (increase temperature and humidity), so to minimize these effects tents were erected as close to $H$. abietis adult emergence as possible (as indicated by destructive sampling of the quarter stumps 4 weeks after nematode application).

\subsection{Effect of timing and method of nematode application on weevil emergence (2005)}

Each of the three nematode species ( $S$. carpocapsae All strain, $S$. feltiae 4CFMO and $H$. downesi K122) was applied both in an aqueous suspension, and as cadavers of nematode-killed $G$. mellonella. Aqueous suspension was applied April 11th 2005, May 6th 2005 or June 6th 2005 at the standard rate and volume (3.5 million IJs/stump in $500 \mathrm{ml}$ of water). Cadavers with nematodes (20 per stump) were applied at the same time as the May aqueous application. A May cadaver application was chosen so that EPN emergence would occur while the majority of immature $H$. abietis were still in the larval stages. In order to determine the concentration of IJs applied to cadaver-treated stumps, harvests of $100 \mathrm{G}$. mellonella cadavers (10 White traps of 10 insects) used for the field application were counted. The mean emergence per $S$. carpocapsae, $H$. downesi and $S$. feltiae cadaver was $475 \pm 26,363 \pm 20$ and $69 \pm 8 \times 10^{3}$, respectively. Based on the fact that 20 cadavers were applied to each stump, stumps treated with S. carpocapsae, H. downesi and S. feltiae received 9.5, 7.3 and 1.4 million $I J s$, respectively.

The dry needle litter was removed and either the nematode suspension was poured onto the soil around the stump in a band approximately $5 \mathrm{~cm}$ wide or the insect cadavers were scattered around the bole of the stump. The litter was then replaced. Ten blocks were set out in a randomized block design, with each block containing 12 nematodetreated stumps ( 3 nematode species, 3 application dates, 1 date with 2 formulations) and 3 untreated control stumps. Adult emergence was assessed as described above for 2005 (Section 2.3). Soil temperature was recorded at a depth of $10 \mathrm{~cm}$ from before the 1st application date until after the final assessment in October 2005, using four probes (Star$\log$ ). The temperature probe was placed at a depth of $10 \mathrm{~cm}$, as the majority of immature $H$. abietis are found less than $8 \mathrm{~cm}$ below the surface (Brixey, 2000). Temperature was recorded every $4 \mathrm{~h}$ and average daily maximum and minimum values calculated. Average minimum and maximum soil temperatures were 9.1 and $9.8^{\circ} \mathrm{C}$ in April 2005, 11.3 and $12.3^{\circ} \mathrm{C}$ in May 2005 and 16 and $17^{\circ} \mathrm{C}$ in June 2005 (Fig. 1). Data on average daily rainfall were obtained from the nearest Met Eireann meteorological station (70 and $26 \mathrm{~km}$ from the experimental site in 2004 and 2005, respectively). Average monthly rainfall remained below $2 \mathrm{~mm}$ /day between the months of April and June in both years. 


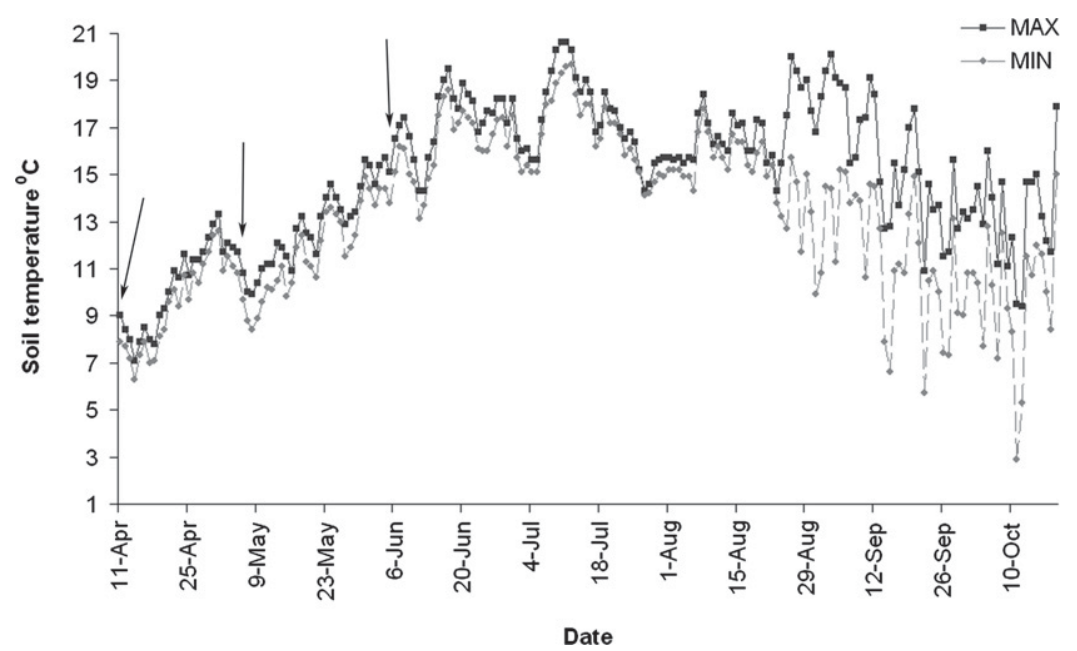

Fig. 1. The maximum and minimum temperature $\left({ }^{\circ} \mathrm{C}\right)$ recorded in the upper $10 \mathrm{~cm}$ of soil at the field trial site in 2005 . Arrows indicate date at which nematodes were applied.

\subsection{Effect of application volume on percentage and location of parasitized weevils}

The standard rate ( 3.5 million IJs/stump) was applied in 500,250 or $125 \mathrm{ml}$ of tap water. Two nematode species were tested: S. carpocapsae All strain and H. downesi K122. An untreated control was also included in each trial. Nematodes were applied to the stumps as described above (Section 2.3). The experiment was set out in a randomized block design, with 1 stump of each treatment. Ten blocks were treated in each of 2004 and 2005.

Stumps were sampled 4 weeks after nematode application. A quarter of each stump was destructively sampled as described by Dillon et al. (2006). The developmental stage, whether alive or dead and location of each $H$. abietis was recorded. Nematode-induced mortality was determined based on the color and consistency of the cadaver in the field. Immature $H$. abietis killed by Steinernema spp. appear light brown (fawn), while $H$. abietis killed by $H$. downesi can turn a variety of colors including red, orange and green. Location was recorded as both vertical distance from the soil surface (depth) and horizontal distance from the bole of the stump.

\subsection{Statistical analysis}

Routine statistics were performed using MINITAB Release 14 for Windows (Minitab Inc, 2003). Significance levels were taken at $P<0.05$. Data were tested for normality using the Anderson Darling test and, where found to be non-normal data, were transformed. The numbers of adult weevils emerging per stump were transformed using the square root transformation. Data for the percentage of insects parasitized were transformed using the arcsine square root transformation. More than two treatments were compared using General Linear Model ANOVA, followed by pairwise comparisons (Tukey's test; alpha $=0.05$ ). Regression analysis on percentage parasitism at each depth and distance was performed using the average values obtained in each year. Regression lines (residual variances, slope and elevation) were compared using Statistix ${ }^{\circledR} 8$ (Analytical Software Statistix 8, 2003).

\section{Results}

\subsection{Effect of nematode application rate on weevil emergence}

In the absence of any control strategy, an average of 79 H. abietis adults emerged per stump in 2004 (July 19thOctober 10th), and 88 per stump in 2005 (July 13th-October 19th) (Fig. 2). When all treatments (nematode species and application rates) including the no nematode control were compared, the number of adults emerging was significantly affected by stump treatment and year $(P<0.001$ and $P<0.05$, respectively), with no interaction between the two factors $(P>0.05)$ (Table 1). Application of $H$. downesi reduced the number of adult $H$. abietis emerging relative to untreated stumps by $75-85 \%$, while $S$. carpocapsae reduced emergence by $18-64 \%$. The number of adult $H$. abietis emerging from stumps treated with $S$. feltiae was reduced by $51-58 \%$ relative to the controls.

When only the numbers of adult $H$. abietis emerging from nematode treated stumps were compared, year was significant $(P<0.05)$, as were nematode species and application rate $(P<0.001$ and $P<0.05$, respectively) (Table 2$)$. Halving the rate of nematodes applied to stumps resulted in reduced control; the result of the treatment with $S$. carpocapsae was more affected $(P=0.08)$ than that with $H$. downesi $(P=0.9)$ or $S$. feltiae $(P=1.00)$.

\subsection{Effect of timing and method of nematode application on weevil emergence (2005)}

Adult emergence was significantly affected by stump treatment ( 1 way ANOVA, $F=7.61, d f=12,134$, $P<0.001$ ) (Fig. 3). All of the nematode treatments (3 


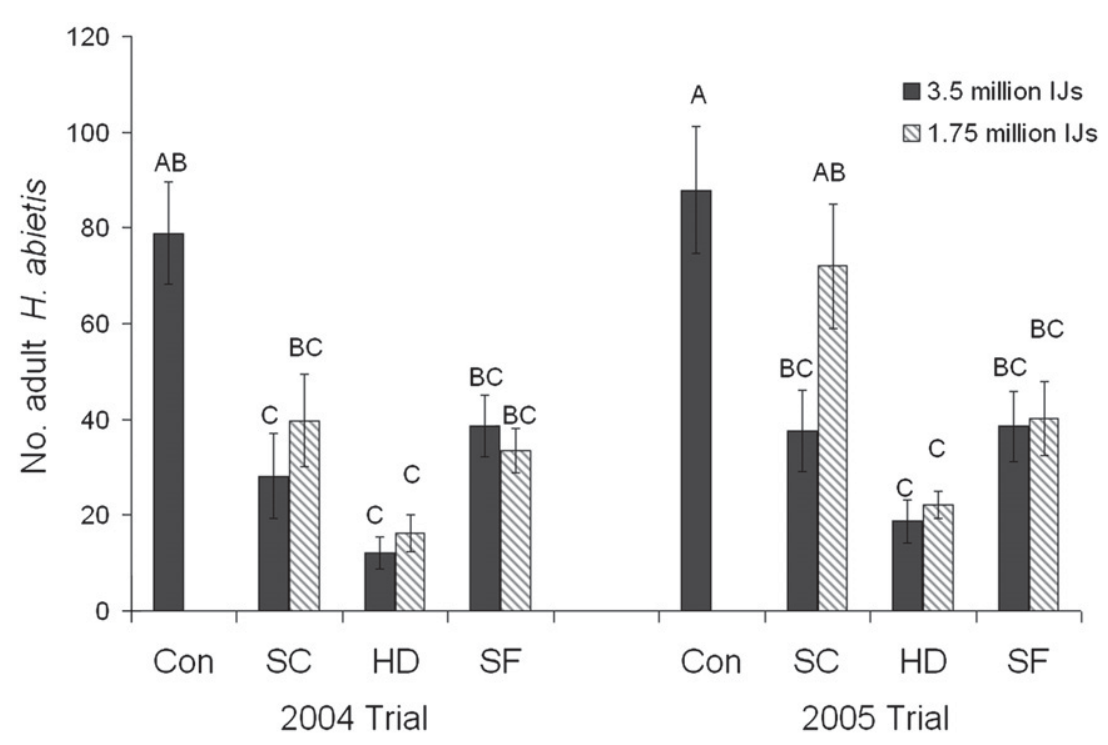

Fig. 2. Number (mean \pm SE) of Hylobius abietis adults emerging per pine stump. Stumps were treated with either 3.5 or 1.75 million infective juveniles (IJs) in $500 \mathrm{ml}$ of water. Emergence was recorded over a period of 10 weeks in 2004 (6-16 weeks after nematode application) and over 12 weeks in 2005 (6-18 weeks after nematode application). Different letters above a column indicate significant differences between treatments (Tukey at $P=0.05$, following ANOVA, $P<0.05)$. Con, Control; SC, Steinernema carpocapsae; HD, Heterorhabditis downesi and SF, Steinernema feltiae. N = 8 stumps in 2004. In 2005, $n=10$ stumps for each nematode treatment and $n=30$ for the control treatment.

Table 1

Analysis of variance results for effect of stump treatment and year on adult Hylobius abietis emergence

\begin{tabular}{lrrl}
\hline & $d f$ & \multicolumn{1}{c}{$F$} & $P$ \\
\hline Treatment (3 nematode species, 2 doses and control) & 6 & 16.85 & $<0.001$ \\
Year & 1 & 4.24 & $<0.05$ \\
Treatment $\times$ Year & 6 & 0.58 & $>0.05$ \\
Error & 132 & & \\
Total & 145 & & \\
\hline
\end{tabular}

Table 2

Analysis of variance results for effect of nematode species, application rate and year on adult Hylobius abietis emergence

\begin{tabular}{lrrl}
\hline & $d f$ & F & $P$ \\
\hline Nematode species (SC, HD, SF) & 2 & 15.40 & $<0.001$ \\
Year & 1 & 4.47 & $<0.05$ \\
Application rate $\left(3.5\right.$ or $1.75 \times 10^{6}$ IJs/stump) & 1 & 4.48 & $<0.05$ \\
Nematode $\times$ Year & 2 & 1.23 & $>0.05$ \\
Nematode $\times$ Application rate & 2 & 2.07 & $>0.05$ \\
Year $\times$ Application rate & 1 & 0.67 & $>0.05$ \\
Nematode $\times$ Year $\times$ Application rate & 2 & 0.28 & $>0.05$ \\
Error & 96 & & \\
Total & 107 & & \\
\hline
\end{tabular}

SC, Steinernema carpocapsae; HD, Heterorhabditis downesi; $\mathrm{SF}=$ S. feltiae.

species, 3 application dates and 2 formulations) significantly reduced the number of adult $H$. abietis emerging from stumps relative to the controls (49-79\%), except the April application of $S$. feltiae $(46 \%)$. When only nematode-treated stumps were compared, nematode species significantly affected adult emergence $(P<0.001)$, but application date and formulation (aqueous vs. cadaver) did not $(P>0.05$ and $P>0.05$, respectively) (Table 3 ).
Both aqueous and cadaver application were effective methods of control, though the former would be more cost effective.

\subsection{Effect of application volume on percentage and location of parasitized weevils}

All of the nematode application volumes resulted in the parasitism of immature $H$. abietis that were developing in the stumps (Fig. 4). When stumps were destructively sampled 4 weeks after nematode application, no weevils were parasitized by nematodes in any of the control stumps in either the 2004 or 2005 trial. When 3.5 million $H$. downesi or $S$. carpocapsae IJs were applied to stumps in 500, 250 or $125 \mathrm{ml}$ of water, the percentage of insects parasitized varied with nematode $(P<0.001)$ and with year $(P<0.01)$, but not with the volume in which the nematodes were applied $(P>0.05)$ (Table 4). There was an interaction between volume and nematode $(P<0.05)$, but not between any of the other factors (Table 4). The percentage parasitism by $H$. downesi tended to decrease as the volume of water decreased (51-35\% in 2004 and $77-49 \%$ in 2005), but this trend was not repeated for $S$. carpocapsae (Fig. 4).

In order to see whether parasitism by nematodes applied in lower volumes of water was more restricted to weevils close to the application zone, we plotted percentage parasitism against depth and distance. As expected, both nematodes moved from the zone of application. Percentage parasitism decreased as distance out from the bole and depth increased in each of the nematode treatments (Figs. 5A and B). Regression lines for all six treatments were compared. For distance, variances did not differ significantly between treatments $\left(\chi^{2}=3.34, d f=5, \quad P>0.05\right)$, and 


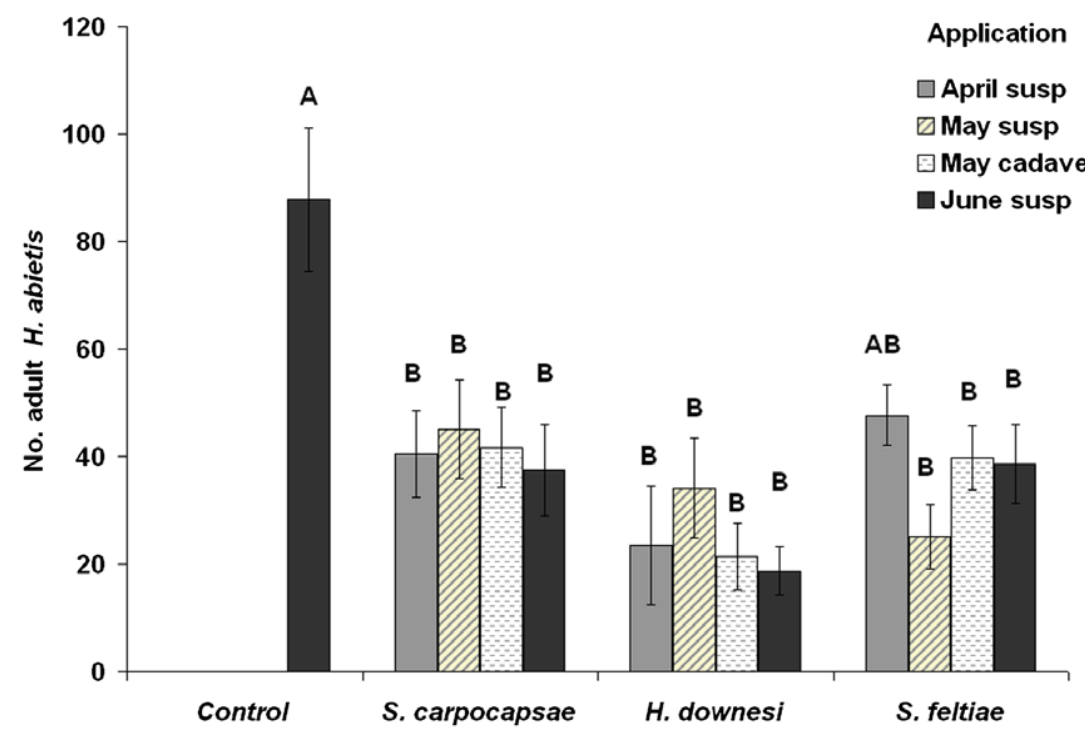

Fig. 3. Number (mean $\pm \mathrm{SE}$ ) of Hylobius abietis adults emerging per pine stump. Stumps were treated with either $3.5 \mathrm{million}$ infective juveniles in $500 \mathrm{ml}$ of water (April, May or June aqueous), or with 20 nematode-killed insects (May cadaver). Based on IJ emergence under laboratory conditions at $20{ }^{\circ} \mathrm{C}$ Steinernema carpocapsae, Steinernema feltiae and Heterorhabditis downesi cadaver-treated stumps received 9.5, 1.4 and $7.3 \times 10^{6}$ IJs per stump. Emergence was recorded over a period of 12 weeks in 2005 (6-18 weeks after nematode application). Different letters above a column indicate significant differences between treatments (Tukey at $P=0.05$, following ANOVA, $P<0.05$ ). $N=10$ stumps for each nematode treatment and $n=30$ for the control treatment.

Table 3

Analysis of variance results for effect of nematode species and application date and formulation of nematode application on adult Hylobius abietis emergence

\begin{tabular}{lrll}
\hline & $d f$ & $F$ & $P$ \\
\hline Nematode species (SC, HD, SF) & 2 & 8.48 & $<0.001$ \\
Application date (April, May or June) & 2 & 0.29 & $>0.05$ \\
Formulation (aqueous and nematode killed insect) & 1 & 0.00 & $>0.05$ \\
Application date $\times$ Nematode & 4 & 1.87 & $>0.05$ \\
Nematode $\times$ Formulation & 2 & 1.90 & $>0.05$ \\
Error & 105 & & \\
Total & 116 & & \\
\hline
\end{tabular}

SC, Steinernema carpocapsae; HD, Heterorhabditis downesi; $\mathrm{SF}=$ S. feltiae.

although elevations differed significantly $(F=6.59, d f=5$, $23, P<0.001)$, slopes did not $(F=0.24 ; d f=5,18, P>0.05)$. The outcome of the analysis by depth was similar: variance $\left(\chi^{2}=3.34, d f=5, P>0.05\right)$; elevation $(F=6.51, d f=5,23$, $P<0.001)$ and slope $(F=0.20, d f=5,18, P>0.05)$.

\subsection{Population structure in control stumps, and parasitism in relation to weevil developmental stage}

Ten control quarter-stumps were sampled 4 weeks after nematode application (19 months after felling) and a total of 283 insects were recovered in 2004 and 362 insects in 2005. In both trials, the majority of the insects (78 and 64\%) were at the pupal stage (Fig. 6). Larvae were all late instar. Adults were present in both trials, and in 2005 a small number $(4 \%)$ had already emerged.

In nematode treated stumps, insect developmental stage and nematode species both significantly influenced percentage parasitism $(P<0.001$ in each case). There was no inter- action between the two factors $(P>0.05)$ (Table 5). A higher percentage of larvae $(60 \%)$ were infected than either pupae $(36 \%)$ or adults $(18 \%)$ (Fig. 7$)$.

\section{Discussion}

While the use of biological control agents may be preferable to certain chemicals from an environmental perspective, a biological control agent will still need to compare favorably in terms of cost and provide reliable predictable control in order to be adopted by growers. The only nematode species to significantly reduce adult $H$. abietis emergence relative to the controls in both years at both application rates was $H$. downesi. The reduction at the standard rate (3.5 million IJs/stump) in 2004 and 2005 (85 and $79 \%$, respectively) was similar to values previously observed for this species in pine (68-87\%) (Dillon et al., 2006). Halving the rate of nematodes applied to stumps resulted in reduced control overall, but the result of the treatment with $S$. carpocapsae was more affected than that with either $H$. downesi or $S$. feltiae. A decrease in the efficacy of $S$. carpocapsae at a lower rate was observed by Brixey (2000), who reported that reducing the rate from 3.5 to 1.25 million IJs/ stump significantly reduced percentage parasitism in pine (51-32\%, respectively), but not in spruce (21-13\%).

The success of $H$. downesi and $S$. carpocapsae applied to stumps from April onwards, when minimum daily soil temperatures remained below $9^{\circ} \mathrm{C}$ for 9 days following application, has profound implications for the feasibility of treating large areas. It is generally recommended that EPN, particularly heterorhabditids, should only be applied when soil temperatures are above $12^{\circ} \mathrm{C}$. It had previously been reported that the window for effective application of 


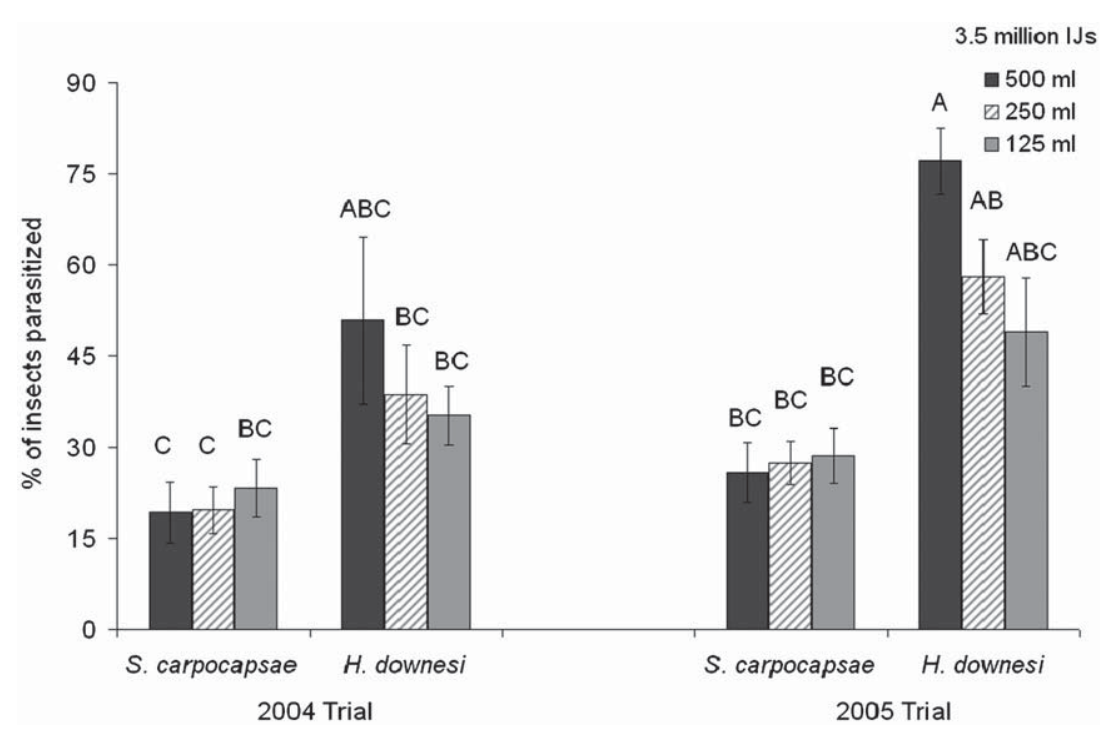

Fig. 4. Percentage (mean $\pm \mathrm{SE}$ ) of Hylobius abietis parasitized by entomopathogenic nematodes (Steinernema carpocapsae and Heterorhabditis downesi) in each of 2 trials, one per year. Pine stumps were treated with 3.5 million infective juveniles (IJs) in 500 , 250 or 125 ml of water. In each trial, quarter stumps were destructively sampled 4 weeks after application of nematodes. Different letters above a column indicate significant differences between treatments (Tukey at $P=0.05$, following ANOVA, $P<0.05$ ). $N=10$ stumps.

Table 4

Analysis of variance results for effect of nematode species, year and application volume on parasitism of Hylobius abietis

\begin{tabular}{lrrl}
\hline & $d f$ & $F$ & $P$ \\
\hline Nematode species (SC and HD) & 1 & 39.83 & $<0.001$ \\
Year & 1 & 9.72 & $<0.01$ \\
Volume (in 500, 250 or 125 ml) & 2 & 1.54 & $>0.05$ \\
Nematode $\times$ Year & 1 & 1.89 & $>0.05$ \\
Nematode $\times$ Volume & 2 & 3.20 & $<0.05$ \\
Year $\times$ Volume & 2 & 0.46 & $>0.05$ \\
Nematode $\times$ Year $\times$ Volume & 2 & 0.39 & $>0.05$ \\
Error & 104 & & \\
Total & 115 & & \\
\hline
\end{tabular}

SC, Steinernema carpocapsae; HD, Heterorhabditis downesi.

S. carpocapsae against $H$. abietis in pine stumps was between mid May and early July (Torr et al., 2005). While some of the insects may have been infected at $9^{\circ} \mathrm{C}$, at least by H. downesi K122 (Griffin and Downes, 1991), it is probable that most became infected and died only after soil temperatures had increased. The April application of S. feltiae was the only treatment that did not significantly reduce $H$. abietis emergence.

The reduced numbers of $H$. abietis emerging from cadaver treated stumps (53-76\%) demonstrate that buried insects can be successfully used to control H. abietis, as has been shown for a number of other insect pests (Creighton and Fassuliotis, 1985; Jansson et al., 1993; Jansson and Lecrone, 1994). Nematodes were applied in cadavers, as this mechanism allows for the slow release of the nematodes over time, nematodes emerging directly into the soil may be of superior quality compare to those applied in an aqueous suspension (Perez et al., 2003; Shapiro-Ilan and Lewis, 1999; Shapiro-Ilan and Glazer, 1996), and the cadaver may afford the IJs some protection from environ- mental conditions, as nematodes remain in the cadaver until local conditions become suitable (Koppenhöfer et al., 1997; Brown and Gaugler, 1997). As the cadavers were applied prior to emergence, we could not know in advance exactly the number of IJs that would emerge under natural conditions due to batch variation. Preliminary laboratory experiments ensured that emergence from the cadavers was in the same order of magnitude as the aqueous application, as confirmed in the post hoc estimates. Based on the IJ emergence counts from laboratory-incubated cadavers, stumps treated with $H$. downesi, S. carpocapsae and S. feltiae nematode killed insects received 7.3, 9.5 and 1.4 million IJs, respectively, compared to the aqueous application rate of 3.5 million IJs/stump. Values estimated from $20^{\circ} \mathrm{C}$-incubated cadavers may overestimate the numbers that emerged in the field where average daily soil minimum and maximum temperature in May 2005 were 9.1 and $9.8^{\circ} \mathrm{C}$, respectively, with maximum soil temperature remaining below $15^{\circ} \mathrm{C}$ for more than 3 weeks following cadaver application. Exposure to low temperatures (including $15^{\circ} \mathrm{C}$ ) can reduce or delay emergence of entomopathogenic nematodes (Brown and Gaugler, 1997), and predation on nematode-killed insects may also have reduced IJ emergence in the field (Baur et al., 1998). For S. feltiae the estimated cadaver application rate (1.4 million $\left.\mathrm{IJ}_{\mathrm{S}} / \mathrm{stump}\right)$, was lower than in the aqueous suspension (3.5 million IJs/stump), but results from the experiments investigating the effect of application rate indicated that halving the rate of $S$. feltiae did not reduce the level of control. For $H$. downesi and $S$. carpocapsae, the estimated cadaver application rate was higher than aqueous suspension rate. If not an overestimate (as discussed above), this may either indicate that the cadaver-nematodes were of inferior quality, which is unlikely (Perez et al., 2003), or that an increased number of 
A

Volume carrier $(\mathrm{ml})$

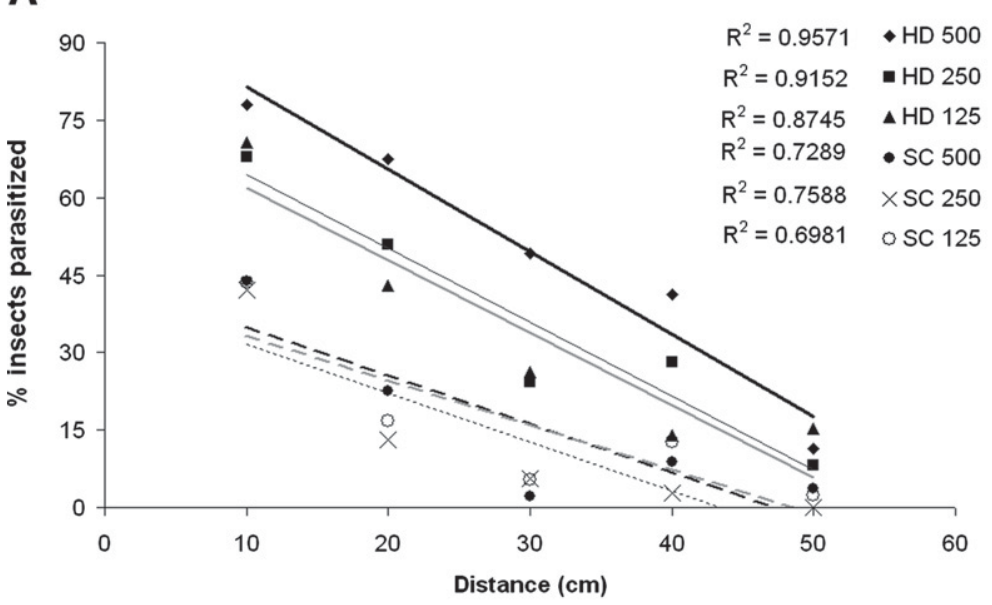

B

Volume carrier $(\mathrm{ml})$

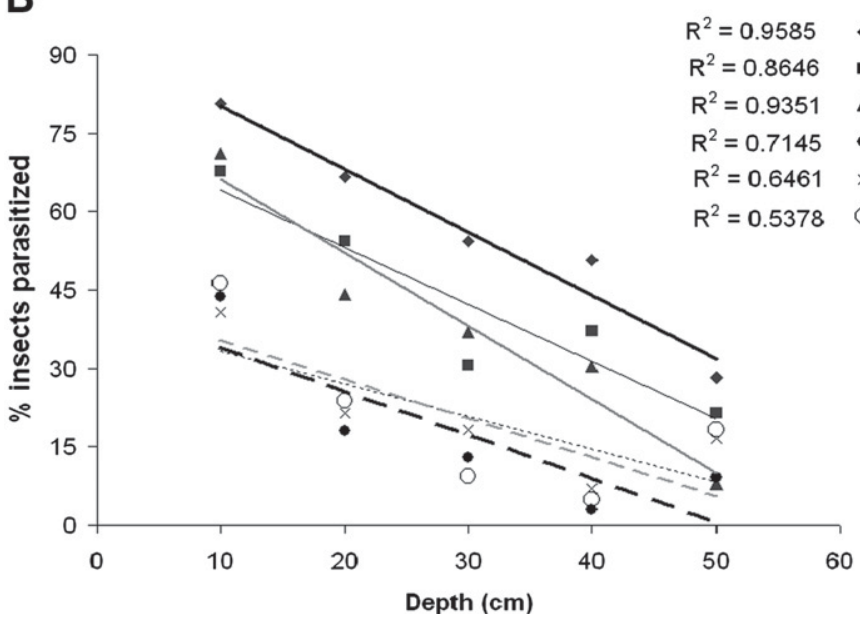

Fig. 5. Effect of horizontal distance from the bole of the stump (A) and depth (B) on the percentage of Hylobius abietis parasitized by Steinernema carpocapsae and Heterorhabditis downesi when pine stumps were treated with 3.5 million infective juveniles (IJs) in 500, 250 or $125 \mathrm{ml}$ of water. Data based on average across 2 years. $\mathrm{SC}=S$. carpocapsae, $\mathrm{HD}=H$. downesi.

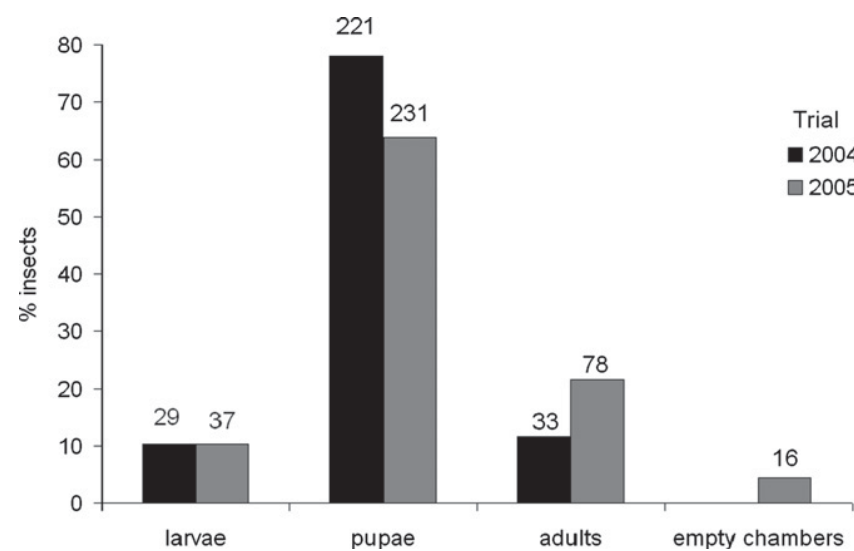

Fig. 6. Population structure of Hylobius abietis (as a percentage of the total number of insects found) in pine quarter stumps at the time of destructive assessment in July 2004 and 2005 (19 months after felling). The number above each column is the total number of insects in the stage. Data are for control stumps that did not receive nematodes.
Table 5

Analysis of variance results for effect of nematode species and Hylobius abietis developmental stage on $H$. abietis parasitism

\begin{tabular}{lrrl}
\hline & $d f$ & $F$ & $P$ \\
\hline Nematode (SC and HD) & 1 & 13.39 & $<0.001$ \\
Developmental stage (larvae, pupae, adults) & 2 & 44.39 & $<0.001$ \\
Nematode $\times$ Developmental stage & 2 & 1.37 & $>0.05$ \\
Error & 309 & & \\
Total & 314 & & \\
\hline SC Steinernema carpocapsae; HD, Heterorhabditis downesi.
\end{tabular}

SC, Steinernema carpocapsae; HD, Heterorhabditis downesi.

nematodes above the standard $3.5 \times 10^{6}$ rate does not give improved control. Although buried cadavers can be successfully used to control $\mathrm{H}$. abietis, it is unlikely that this method will ever be used in commercial forestry in Europe due to the high labor costs associated with the production of nematodes in insects.

Species of entomopathogenic nematode are reported to display differing foraging strategies, on a continuum from extreme ambush foragers to extreme cruisers (Campbell and Gaugler, 1997; Grewal et al., 1994; Lewis et al., 1992). 


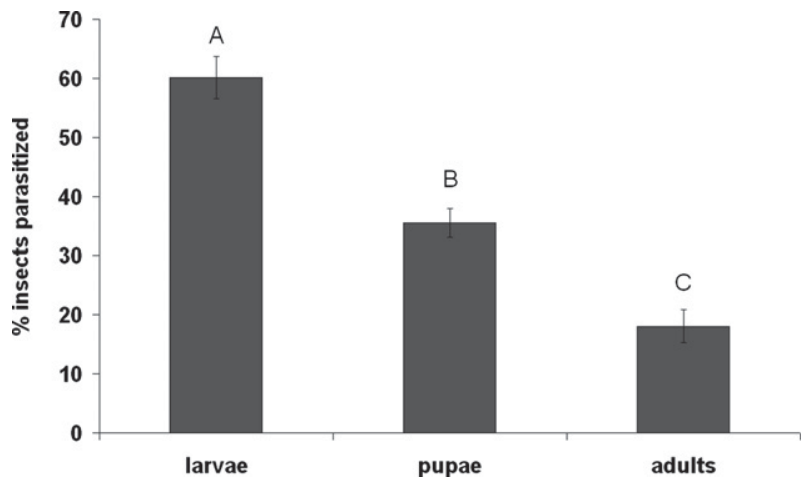

Fig. 7. Percentage (mean $\pm \mathrm{SE}$ ) of each developmental stage of Hylobius abietis parasitized by entomopathogenic nematodes. Pine stumps were destructively sampled 4 weeks after application of 3.5 million nematode infective juveniles/stump. Different letters above a column indicate significant differences between stages (Tukey at $P=0.05$, following ANOVA, $P<0.05)$. Data for Heterorhabditis downesi and Steinernema carpocapsae in 2004 and 2005 combined.

Steinernema carpocapsae is described as a classic ambush forager, and laboratory and field studies have demonstrated that IJs of this species occur on or near the soil surface (Campbell et al., 1996), and are poorly adapted to moving through the soil in search of subterranean sedentary insects (Ferguson et al., 1995; van Tol et al., 1998; Gaugler et al., 1997). Nevertheless, S. carpocapsae has been shown to parasitize subterranean insects. S. carpocapsae infected $H$. abietis have been recovered up to a depth $30 \mathrm{~cm}$ and a distance of $70 \mathrm{~cm}$ from where the nematode was applied (Dillon et al., 2006; Brixey et al., 2006) and Dillon et al. (2006) concluded that either the distinction between ambusher and cruiser is overemphasized, or that nematodes may have been passively carried along the "routeways" supplied by the stump. The volume of water in which the nematodes were applied was reduced up to fourfold in the present trials reducing the probability that the nematodes were passively carried along the roots. As average monthly rainfall over the duration of the experiments remained below $2 \mathrm{~mm}$ per day, we do not expect rainfall alone to have resulted in the dispersal of EPN from the zone of application. Although overall, fewer weevils were parasitized by $S$. carpocapsae than by the cruiser nematode, $H$. downesi, the rate at which parasitism declined with distance and depth did not differ between species. The fact that infected weevils were again recovered up to $49 \mathrm{~cm}$ out from the zone of application and $49 \mathrm{~cm}$ below the soil surface, even when $S$. carpocapsae was applied in a very small volume of water, suggests either that nematodes disperse actively, or that the volume of water in which the nematodes are applied is not important if rainfall is adequate.

The practice of dipping seedlings in alpha-cypermethrin prior to planting, followed by a single post planting application of alpha-cypermethrin, currently costs $€ 170-260 /$ ha based on an average restocking density of 2500 seedlings/ ha. As chemical protection is not $100 \%$ effective, restocking a site following weevil damage is common practice and once these restocking costs are taken into account, the cost of chemical control rises to $€ 430-860$ ha (Willoughby et al., 2004). In 2005, the Forestry Commission UK applied $S$. carpocapsae to approximately 500 ha at a concentration of 3.5 million IJs/stump and a cost of $€ 500 /$ ha (S. Heritage pers. comm., 2006). Although $H$. downesi is not currently commercially produced, if costs were similar to those of $H$. bacteriophora or $S$. carpocapsae (€700 per 5 billion IJs, Enema 2006), then the nematodes required for an application of 1.75 million IJs/stump would cost in the region of $€ 200 /$ ha (based on final felling density of 800 stumps/ha). Including application costs of $€ 160 /$ ha (Torr et al., 2005), it could be possible to manage $H$. abietis for as little as $€ 360 /$ ha, which compares favorably with current chemical insecticides.

\section{Conclusion}

Two basic elements are necessary for nematodes to be successful: a suitable nematode for the target pest and favorable economics (Shapiro-Ilan et al., 2002). We demonstrate that population suppression of $H$. abietis using entomopathogenic nematodes is a viable option. Nematodes can be applied as early as April (16 months after felling), when average soil temperatures are approximately $9^{\circ} \mathrm{C}$; and they can be applied as an aqueous suspension or as infected insect cadavers. $H$. downesi was the only species to give consistent control even when application rate was halved to 1.75 million IJs/stump, reinforcing the conclusion of our previous trials (Dillon et al., 2006) that this is the most appropriate species for use against $H$. abietis. If $H$. downesi can be commercially produced at costs similar to $H$. bacteriophora, and applied at a rate of 1.75 million IJs per stump, then it may offer an affordable alternative to the current chemical insecticide regime.

\section{Acknowledgments}

Trials were conducted under license (TA003/01) from the Pesticide Control Services of the Irish Department of Agriculture and Food. INTERREG, COFORD and Coillte Teoranta provided financial assistance and technical support. We thank the staff and summer students of the Biology Department, NUIM, for their assistance with field trials. The authors are grateful to Koppert Biological Systems (Holland) for supplying nematodes.

\section{References}

Analytical software Statistix 8, 2003. Statistix 8 User's manual: Analytical software Statistix 8, Tallahassee, Florida, USA.

Baur, M.E., Kaya, H.K., Strong, D.R., 1998. Foraging ants as scavengers on entomopathogenic nematode-killed insects. Biol. Control 12, 231-236.

Brixey, J., 2000. The use of entomopathogenic nematodes to control the immature stages of the large pine weevil, Hylobius abietis. PhD Thesis, University of Reading, UK.

Brixey, J.M., Moore, R., Milner, A.D., 2006. Effect of entomopathogenic nematode (Steinernema carpocapsae Weiser) application technique on the efficacy and distribution of infection of the large pine weevil (Hylo- 
bius abietis L.) in stumps of Sitka spruce (Picea sitchensis Carr.) created at different times. Forest Ecol. Manag. 226, 161-172.

Brown, I.M., Gaugler, R., 1997. Temperature and humidity influence emergence and survival of entomopathogenic nematodes. Nematologica 43 , 363-373

Burman, M., Pye, A.E., Nojd, N.O., 1979. Preliminary field trials of the nematode Neoaplectana carpocapsae against larvae of the large pine weevil, Hylobius abietis (Coleoptera: Curculionidae). Ann. Entomol. Fenn. 45, 88 .

Campbell, J.F., Gaugler, R.R., 1997. Inter-specific variation in entomopathogenic nematode foraging strategy: Dichotomy or variation along a continuum? Fund. Appl. Nematol. 20, 393-398.

Campbell, J.F., Lewis, E.E., Yoder, F., Gaugler, R., 1996. Spatial and temporal distribution of entomopathogenic nematodes in turf. Parasitology $113,473-482$.

Collins, S.A., 1993. The potential of entomopathogenic nematodes to reduce damage by Hylobius abietis L. PhD Thesis, University of London, Imperial College of Science, Technology and Medicine, UK.

Creighton, C.S., Fassuliotis, G., 1985. Heterorhabditis sp. (Nematoda: Heterorhabditidae): A nematode parasite isolated from the banded cucumber beetle Diabrotica balteata. J. Nematol. 17, 150-153.

Dillon, A.B., 2003. Biological control of the large pine weevil, Hylobius abietis L., (Coleoptera: Curculionidae) using entomopathogenic nematodes, PhD Thesis, National University of Ireland, Maynooth.

Dillon, A.B., Ward, D., Downes, M.J., Griffin, C.T., 2006. Suppression of the large pine weevil Hylobius abietis (Coleoptera: Curculionidae) in pine stumps by entomopathogenic nematodes with different foraging strategies. Biol. Control 38, 217-226.

Eidmann, H.H., 1974. Hylobius Schönh. In: Schwenke, W. (Ed.), Die Forstchädlinge Europas II Käfer. Paul Parey, Berlin, pp. 275-293.

Evans, H., Moore, R. Heritage, S., Wainhouse, D., 2004. Developments in the integrated management of the pine weevil, a pest of restocking in conifer plantations. In Forest Research Annual Report and Accounts 2003-2004, Forestry Commission, UK, pp.78-87.

Ferguson, C.S., Schroeder, P.C., Shields, E.J., 1995. Vertical distribution, persistence and activity of entomopathogenic nematodes (Nematoda: Heterorhabditidae and Steinernematidae) in alfalfa snout beetle (Coleoptera: Curculionidae) infested fields. Environ. Entomol. 24, 149-158.

Forst, S., Dowds, B., Boemare, N., Stackebrandt, E., 1997. Xenorhabdus and Photorhabdus spp.: Bugs that kill bugs. Annu. Rev. Microbiol. 51, 47-72.

Gaugler, R., Lewis, E., Stuart, R.J., 1997. Ecology in the service of biological control: the case of entomopathogenic nematodes. Oecologia 109 , 483-489.

Grewal, P.S., Lewis, E.E., Gaugler, R., Campbell, J.F., 1994. Host finding behaviour as a predictor of foraging strategy in entomopathogenic nematodes. Parasitology 108, 207-215.

Grewal, P.S., Ehlers, R.U., Shapiro-Ilan, D.J., 2005. Nematodes as Biocontrol Agents. CABI Publishing, Wallingford, UK.

Griffin, C.T., Downes, M.J., 1991. Temperature activity in Heterorhabditis sp. (Nematoda, Heterorhabditidae). Nematologica 37, 83-91.

Heritage S., Moore R., 2001. The assessment of site characteristics as part of a management strategy to reduce damage by Hylobius. Information note 38. Forestry Commission, Edinburgh, UK.

Jansson, R.K., Lecrone, S.H., 1994. Application methods for entomopathogenic nematodes (Rhabditida: Heterorhabditidae): aqueous suspensions versus infected cadavers. Fla. Entomol. 77, 281-284.

Jansson, R.K., Lecrone, S.H., Gaugler, R., 1993. Field efficiency and persistence of entomopathogenic nematodes (Rhabditida: Steinernematidae, Heterorhabditidae) for control of sweetpotato weevil (Coleoptera: Apionidae) in southern Florida. J. Econ. Entomol. 86, 1055-1063.

Kenis, M., Wegensteiner, R., Griffin, C.T., 2004. Parasitoids, predators, nematodes and pathogens associated with bark weevil pests. In: Lieutier, F., Day, K.R., Battisti, A., Gregoire, J.C., Evans, H.F. (Eds.), Bark and Wood Boring Insects in Living Trees in Europe, a Synthesis. Kluwer Academic Publishers, Dordrecht, Netherlands, pp. 395-414.
Koppenhöfer, A.M., Baur, M.E., Stock, S.P., Choo, H.Y., Chinnasri, B., Kaya, H.K., 1997. Survival of entomopathogenic nematodes within host cadavers in dry soil. Appl. Soil Ecol. 6, 231-240.

Langstrom, B., Day, K.R., 2004. Damage control and management of weevil pests, especially Hylobius abietis. In: Lieutier, F., Day, K.R., Battisti, A., Gregoire, J.C., Evans, H.F. (Eds.), Bark and Wood Boring Insects in Living Trees in Europe, a Synthesis. Kluwer Academic Publishers, Dordrecht, Netherlands, pp. 415-444.

Leather, S.R., Day, K.R., Salisbury, A.N., 1999. The biology and ecology of the large pine weevil, Hylobius abietis (Coleoptera: Curculionidae): a problem of dispersal? Bull. Entomol. Res. 89, 3-16.

Lewis, E.E., Gaugler, R., Harrison, R., 1992. Entomopathogenic nematode host finding: response to host contact cues by cruise and ambush foragers. Parasitology 105, 103-107.

Lewis, E.E., Shapiro-Ilan, D.I., McCoy, C., 2002. Developmental rates in entomopathogenic nematodes: infected hosts vs aqueous suspension. J. Nematol. 34, 340-342.

Minitab Inc. (2003). MINITAB Statistical Software, Release 14 for Windows, State College, Pennsylvania.

Moore, R., Brixey, J., Milner, A.D., 2004. Effect of time of year on the development of immature stages of the large pine weevil (Hylobius abietis L.) in stumps of Sitka spruce (Picea sitchensis Carr.) and influence of felling date on their growth, density and distribution. J. Appl. Entomol. 128, 167-176.

Nordenhem, H., Nordlander, G., 1994. Olfactory oriented migration through soil by root living Hylobius abietis (L.) larvae (Col.: Curculionidae). J. Appl. Entomol. 117, 457-462.

Nordlander, G., 1987. A method for trapping Hylobius abietis (L.) larvae with a standardised bait and its potential for forecasting seedling damage. Scan. J. Forest Res. 2, 199-213.

Nordlander, G., Eidmann, H.E., Jacobsson, U., Nordenhem, H., Sjodin, K., 1986. Orientation of the pine weevil Hylobius abietis to underground sources of host volatiles. Entomol. Exp. Appl. 41, 91-100.

Norlander, G., Nordenhem, H., Bylund, H., 1997. Oviposition pattern of the pine weevil, Hylobius abietis. Entomol. Exp. Appl. 85, 1-9.

Perez, E.E., Lewis, E.E., Shapiro-Ilan, D.I., 2003. Impact of the host cadaver on survival and infectivity of entomopathogenic nematodes (Rhabditida: Steinernematidae and Heterorhabditidae) under desiccating conditions. J. Invertebr. Pathol. 82, 111-118.

Petersson, M., Örlander, G., Nordlander, G., 2005. Soil features affecting damage to conifer seedlings by the pine weevil Hylobius abietis. Forestry 78, 83-92.

Pye, A.E., Burman, M., 1978. Neoaplectana carpocapsae: Infection and reproduction in large pine weevil larvae, Hylobius abietis. Exp. Parasitol. $46,1-11$.

Rose, D., Leather, S.R., Matthews, G.A., 2005. Recognition and avoidance of insecticide-treated Scots pine (Pinus sylvstris) by Hylobius abietis (Coleoptera: Curculionidae): implications for pest management strategies. Agr. Forest Entomol. 7, 187-191.

Shapiro-Ilan, D.I., Glazer, I., 1996. Comparison of entomopathogenic nematode dispersal from infected hosts versus aqueous suspensions. Environ. Entomol. 25, 1455-1461.

Shapiro-Ilan, D.I., Lewis, E.E., 1999. Infectivity of entomopathogenic nematode dispersal from cadavers vs aqueous applications. Environ. Entomol. 28, 907-911.

Shapiro-Ilan, D.I., Gouge, D.H., Koppenhofer, A.M., 2002. Factors affecting commercial success: case studies in cotton, turf and citrus. In: Gaugler, R. (Ed.), Entomopathogenic Nematology. CABI Publishing, New york, pp. 333-355.

Shapiro-Ilan, D.I., Lewis, E.E., Tedders, W.L., 2003. Superior efficacy observed in entomopathogenic nematodes applied in infected-host cadavers compared with application in aqueous suspension. J. Invertebr. Pathol. 83, 270-272.

Stock, S.P., Griffin, C.T., Burnell, A.M., 2002. Morphological characterization of three isolates of Heterorhabditis Poinar 1976 from the 'Irish group' (Nematoda: Rhabditida: Heterorhabditidae) and additional evidence supporting their recognition as a distinct species, H. downesi n. sp. Systematic Parasitol. 51, 95-106. 
Torr, P., Wilson, M.J., Heritage, S., 2005. Forestry applications. In: Grewal, P.S., Ehlers, R.U., Shapiro-Ilan, D.J. (Eds.), Nematodes As Biocontrol Agents. CABI Publishing, Wallingford, UK, pp. 281-294.

van Tol, R.W.H.M., van Bezooijen, J., Ketelaars, T.A.C.M., 1998. Searching behaviour of entomopathogenic nematodes: roots and soil temperature determine success of the black vine weevil (Otiorhynchus sulcatus) control. IOBC Bull. 21, 187-191.
Willoughby I., Evans, H., Gibbs, J., Pepper, H., Gregory, S., Dewar J., Nisbet, T., Pratt, J. McKay, H., Siddon, R., Mayle, B, Heritage, S., Ferris, R., Trout, R., 2004. Reducing pesticide use in forestry. Forestry commission practical guide. Forestry commission, Edinburgh, UK.

Woodring, J.L., Kaya, H.K., 1988. Steinernematid and Heterorhabditid Nematodes: A handbook of techniques. Arkansas Agricultural Experiment Station, Fayetteville, Arkansas, Southern Cooperative Series Bulletin 331. 